
Associate Professor of Department of Marketing and Logistics Lviv Polytechnic National University

(Lviv, Ukraine)

Kindrat Serhii

student of the Department of Marketing and Logistics Lviv Polytechnic National University

(Lviv, Ukraine)

\title{
THE LIKE ECONOMIC PHENOMENON
}

The article describes the main aspects of the impact of social networking tools such as: likes, "shares" and comments on their users, and examines the change in demand for a product or service of a company by using enterprises Internet marketing tools. The factors that influence the increase in likes, reposts and feedback from social network users were identified. The target audience (target customers) of companies (brands) is analyzed. The main advantages and disadvantages of using "likes" on social networks are highlighted, with examples of the detrimental effect of likes on the young generation. The results of our own research on the impact of likes, shares and user's feedback on increasing conversion and demand for a product or service; recommendations for the qualitative and optimized use of social networks and their tools for promoting enterprise products have been developed.

Keywords: marketplace, marketing communications, internet marketing, social media marketing, brand promotion.

\section{DOI: 10.15276/mdt.3.4.2019.5}

Statement of the problem in general form and it's connection with important scientific or practical tasks. With each passing decade, the tools of marketing influence on consumers have been changing: booklets and brochures have been replaced with advertising banners, and city-light have been replaced with flag poles. However, in the 21 st century, such marketing tools are outdated, and even in some situations do not live up the expectations of marketers. Therefore, more tasks are being arised in what ways a marketer can attract a customer's attention and make him buy a particular product or service. Professional SMM marketers will give a simple answer to the above question: "likes" and sharings are the main hidden tools to encourage customers to make a purchase. Social networks have become a platform for promoting a product and service, where, through liking, sharing and commenting functions, a firm can grow its potential customer base in a short period of time. Properly defined target audience, high-quality content are the main tools for attracting consumer attention and getting the desired "Like" or share.

The economic performance of an enterprise depends on the proper and quality conduction of its promotional activities on social networks, and the indicators that confirm the success of the SMM campaign are obviously the number of likes, sharings and comments. Today, the value of these indicators forms the brand of the company.

(C) 2019 The Authors. This is an open access article under the CC BY license (http://creativecommons.org/licenses/by/4.0) 
Initially, the idea of creating social networks was to facilitate communication between members of the public, and in the process of improving and modifying such networks began to acquire clear signs of promotion channel. It is not surprisingly, because advertising is always placed on areas with the largest concentration of people. The question about research of customer engagement tools and their psychological impact on people arose.

Analysis of the latest research and publications, which initiated the solution of this problem and on which the author relies. Psychologists call this the effect of attachment: social proof stimulates people to repeat other people's actions if they are convinced that such actions are correct. Social proof is a powerful tool for influencing buyers' purchasing decisions, building consumer confidence, and forcing users to tell about company to other people (on the principle of "word of mouth") [1]. By its nature, humanity tends to replicate certain actions when a large number of people act in the same way at the same time. As an example, the great number of likes on a video presentation of a particular product encourages others to view this video, analyze it and, shortly, buy this recently launched product. Therefore, it is the social networks, with their functions of "likes", "repost", etc., that have become the platform for selling goods in the 21 st century.

The analysis of literary sources shows that in the scientific literature insufficient attention is paid to studies of the influence of "likes" on users of social networks, although foreign scientists, psychologists, business experts such as UD Scott [2], D. Myers [3] partially explored this issue. As an example, in the book The Way to Customer, KT Friedlander wrote: "The ultimate goal of any advertisement is to influence the mind of a person to such an extent as to induce him to perform a certain act, which consists mainly in the purchase of the product" [4]. Contemporary authors are also researching consumer psychology to a greater extent. R. Chaldini [5] noted that consumers think stereotypically and act on the principle that "everything that is confirmed by a lot of feedback from other customers automatically becomes a good product and the customer buys it." Author of the book Marketing the Future. Growth hacking $\gg \mathrm{R}$. Holiday changed the established concept of marketing and believes that nowadays the" king of advertising "is Internet marketing [6]. It is worth mentioning the study of scientists at Harvard University, who came to the conclusion that increasing the amount of something, in our case are likes, promotes the poduction of dopamine in the human body, a chemical that is produced by our brain, and plays a major role in motivating human behavior [7]. In the context of social marketing, this means that the more likes, shares, and comments a user sees under a promotional post, the more motivating he/she is to view and engage with the advertisement.

The influence of social proof theory proposed by Robert Chaldini [5] is confirmed in social networks such as Facebook, Twitter, Instagram, YouTube, etc. Users perceive the content, and it influences them precisely through the number of followers, likes, and views. Most users think that if something is appealing to many people, it is good content. So, one research has found that a Twitter user with a million followers is perceived as more reliable and competent than a user with a thousand followers [8].

A recent scientific experiment by three scientists from Israel and the United States has proved the effectiveness of the number of likes on social media advertising and information posts. The researchers have experimented with two social news portals, Digg and Reddit, for five months. They were putting an unlimited number of pluses (or minuses) into the comment of a randomly selected post and then they watched the reaction of users. The results, published last summer, surprised many people: the probability that a site visitor would approve a comment after a fabricated number of likes, increased by $32 \%$, and on average, publications with false high popularity received an additional $25 \%$ of the pluses. At the same time, negative manipulation had no such effect. No user will never refuse to consider the opinion of others: this is an extremely efficient decision-making algorithm in a resource-constrained environment. 
So, the algorithm works as follows: a sharp increase in the number of likes - the emergence of interest in users - direct action by the user (move on to post, advertising, etc.) - the result (reading a published article, watching a video, buying a product, ordering a service) [9]. Good ratings draw people to objects: for example when one wants to watch a movie in the evening, one chooses the movie with the highest rating. This is what most companies use, that are undoubtedly tempting people to buy a product that is very popular. And in order to provide the popularity of your product, it is necessary to prove to the client that the product is characterized by high demand. In the case of social media, this is the number of likes, comments or shares.

SMM-expert, blogger Mykola Malukha finds only the positive aspects of being able to comment, like, or share a post. "For example, it is difficult for you to determine how good or bad the written material is, in fact, it is impossible, except by the number of publications in other editors. But in this way, a small amount of material is estimated. And most consider it as a simple reading of the text. There are likes, shares, and comments that make it clear how good the written material was, how much it was perceived by the audience. This is free marketing analysis, free analytics for the publication, which can then be used further", Mykola Malukha noted. That is why most brands have opposed the ban on likes on social media, as this is the main identifier for determining the popularity, quality, and effectiveness of advertising [10].

Internet marketers are clearly aware that the sale of a product requires the user interest. It mainly arises in two cases: the quality of the content, for example, the great photo labeled "Free shopping" will attract the attention of anyone, and the second aspect stands for growthhacking, that is, the rapid promotion of any posts or advertisements which contain a call to action. Otherwise, how to explain a photo of an ordinary chicken egg, the author of the photo asked Instagram users to "like" it and thus do a world record number of likes. In less than 30 days, the photo gained a record number of likes - more than 31 million. The user feels involved in the implementation of "something important", so he becomes a participant of such "action" and puts "likes" without any doubts. If marketers follow this algorithm, sales can increase rapidly [11].

In addition, the paradox of "lots of likes" justified itself in increasing the number of orders, that is, displaying favors under certain advertising is effective for the process of selling a product or service on the Internet, and there is a negative impact of this tool. The fact that "likes" is a good tool for business and there is nothing wrong with promoting it, however, with regard to people's psychical health, one can say with certainty - communication in real life and removal from social media have more advantages of [12]. "Likes" is the main reason why people and companies to do a social posting. Therefore, even before buying good and services on the Internet, first you need to be guided by "common sense" and by your own analysis and pay less attention to positive/negative reviews, the number of likes, etc., the user is not insured to the fact that the comments will be able false and "likes" will be able artificially enlarged.

The impact of social media tools has been explained by both psychological and social aspects. However, it is worth exploring the economic impact of likes, comments, and sharing in more detail. Is it advisable for a company to use new methods of attracting customers using social media? Maybe offline sales are more effective? The answers to these questions will determine which promotion tools are most effective in the economic context of the problem. Proving that a company will make more profit from using online platforms to promote goods and services than from traditional advertising methods will orient all other companies and brands to the use of the newer tool, which is defined as a separate type of marketing - SMM.

Selection of previously unresolved parts of the general problem addressed by the article. The analysis shows that there are no publications in the scientific literature devoted to the study of the economic phenomenon of "likes" and their influence on the formation of demand for goods and services. 
The substantiation of psychological influence on the consumer is present in many scientific works and publications. However, research into social networking tools has received less attention and importance. The tendency to attract customers through Internet channels using the psychological influence of the number of "likes" and reposts is becoming more common, so the question of researching on this topic has become more detailed.

Formulation of the purpose of the article (statement of the problem). The purpose of this article is to research a study on the impact of likes, sharing and comments, as the main functions of social networks, on the formation of demand for a product or service.

To achieve this goal, the following tasks were formed:

- to clarify the economic expediency of using social networking tools such as "likes", reposts and comments;

- identify the main parameters in social networks, by which the consumer determines the popularity of the company, product or service;

- to investigate the main advantages and disadvantages of likes as the main indicator of the popularity of advertising post;

- give an example of qualitative and bad content on a company social page;

- to cover the results of own research on the attitude of respondents to the social networking tools being researched;

- to offer recommendations on the qualitative and optimized use of social networks and their tools for promoting the products of enterprises.

Statement of the main material of the research with full justification of the scientific results obtained. Creating creative messaging for customers has always been a top priority for marketers, promoters, and sales staff. Now, this is the main task of the person responsible for maintaining social networks of the company, that is, social media marketer. The main goal of social media marketing is an accessible and creative message posted on a social platform, which must attract the attention of the user, as well as make himlher respond to the message through like or repost. A large number of likes and reposts have a hidden influence on the consumer when making a purchase decision. By positive reaction to a product-specific post (like or reposting), the user automatically leave positive feedback on that product. Thus, it is scientifically proven that with an increase in positive product reviews, the value of conversion increases, and with an increase in conversion value, an increase in sales is guaranteed [13].

As an example, consider fig. 1, which graphically depicts the relationship between product conversation value and conversion value (The conversation index).

The feedback, in this case, is not just about writing a positive comment about a product from a customer, it's about any action taken by a social network user about a business such as like, repost, and comment. These are the main ingredients that affect sales growth and are actively sought after by marketers.

The parameters on social networks by which the consumer determines the popularity, reliability and trust of other customers to the company, and in particular to its product or service:

1. Number of followers. The large number of subscribers on the company social page tells the client about the popularity of the company. The customer's trust in the company automatically increases.

2. Number of likes. Likes on social media are not only expressions of one's emotions, but also a great tool for marketers. It is clear that the greater the number of "likes" on a post about a particular product, the greater the likelihood that demand for that product is growing. It is important to note that the number of followers and likes must be comparable. That is, if a company has 10,000 followers on the page, and the average number of likes varies from 10-15, then most likely, the company used unfair tools to increase the subscription on its own social page. 


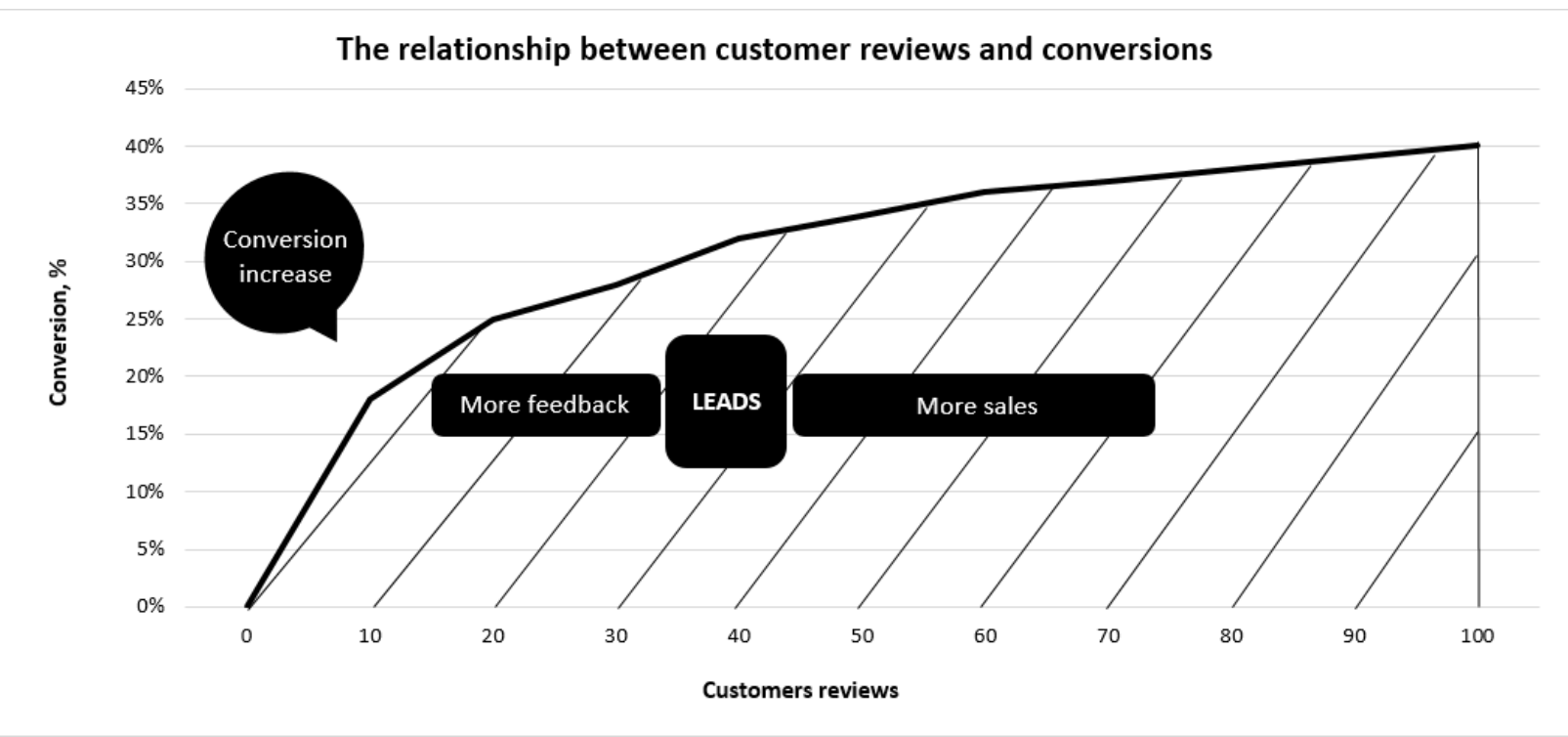

Figure 1. The relationship between customer reviews and conversions *Source: Compiled by authors [1]

The attentive client will immediately understand that the audience of such a company is fake and does not respond to the products offered by the company.

3. Sharing or reposting. Sharing on top social networks such as Facebook and Twitter drives sales. According to Vision Critical, 2 out of 5 users on these social networks have ever made a purchase by sharing or liking the product. Facebook is most effective in this case - about a third of its users have purchased the product after reposting it with a presentation in a post [1].

In its turn, the social media marketer in creating an interesting post is guided by such three components as: defining a goal - reaching a large number of users, a message aimed at the right audience and quality content (fig. 2).

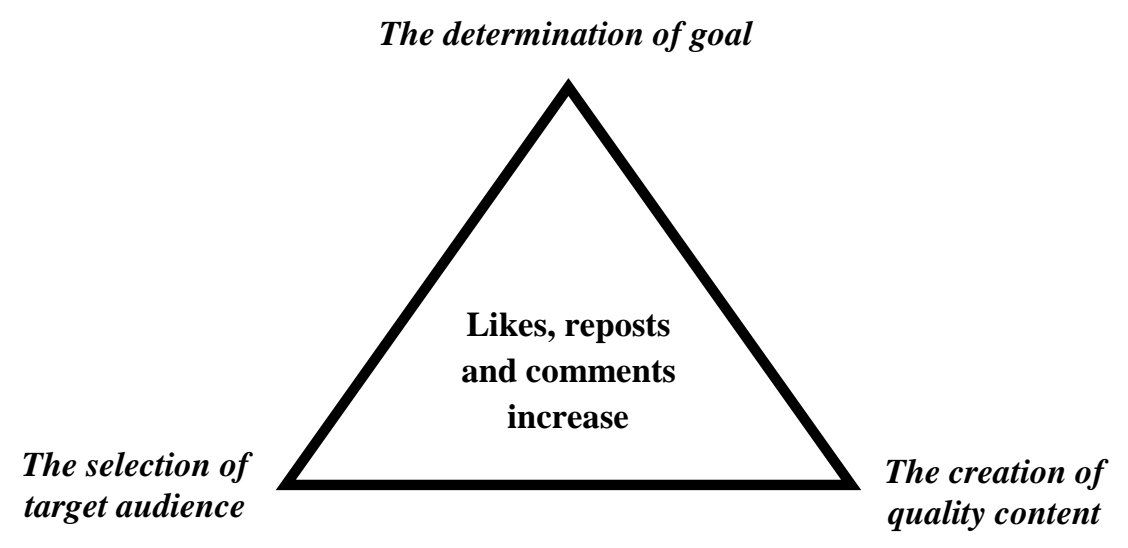

Figure 2. SMM features that increase the likes, reposts and feedback of users

* Source: Compiled by authors based on their own research 
According to VisionCritical, 30\% of Facebook users and 17\% of Twitter users indicate their intention to buy this product after clicking "like" or reposting. In parallel, $70 \%$ of Twitter users plan to make a purchase in the near future, and this index has reached $60 \%$ on the social network Facebook. In $90 \%$ of cases like or repost in the process of finding information about a product by a user of any social network leads to purchase [14, 15].

It is worth considering how psychologically affecting the number of "likes" on the consumer's intention to buy the product. This is explained by the so-called effect of quantity if, when a user sees that a post with a certain product has received more than 1000 likes, he automatically realizes that the product is popular and when planning purchase the consumer is likely to turn to the company where the number of "likes" was highest, taking into account the number of "likes" of competitors. According to the Pareto principle, $20 \%$ of user reviews are likely to provide $80 \%$ of the company's sales in the future. Up to $20 \%$ of reviews include the same number of likes, reposts, and sharings [16].

It is also clear that in an effort to get the most likes and reps, companies can also use unscrupulous tools to increase them, the so-called "cheat". Therefore, more and more SMM marketers are setting the goal - quality content, that means maintaining a company page implies its relevant content that will appeal to the audience and will cause some emotions when viewing a particular post. Positive emotions after reading the advertisement cause the user to desire to interact with the company: a simple "like", repost of advertising or writing their own response under this advertisement. For example, a survey of 112 respondents, which found that $62 \%$ of respondents did not consider the number of likes such as quality content, and $49 \%$ of respondents rated the popularity of the advertisement not by the number of likes but by the number of positive comments.

When marketers actively use the phenomenon of "likes" and other social networking tools, the question arises of the effectiveness of this effect over time. How long will the consumer request the purchase of the product? How long does it take to wait for some action from a client? But do we have to wait at all? According to his own research, after the user has put a "like" on a certain post with a product that is interesting to him, he buys the product for once a week in average. Of course, his choice is influenced by factors other than likes. Before making a purchase, the consumer actively researches all descriptions of the characteristics of the product and reads reviews. And again, the number of "likes" on the reviews of other customers subconsciously influences the decision to buy the product [17]. A similar effect of mass recognition of the goods by consumers was cited by Ryan Holiday in his book Marketing the Future. Each put up like "like" or repost signifies an even greater number of new "likes" and comments, similar to one of the effects of mass communication [6].

The authors' own observations regarding the increase in the volume of profit while actively running a page on the social Instagram network confirm the relevance of the conducted research. So, when photographing went into business, it was necessary to keep track of expenses and revenues, and with the help of Instagram's analytical tools, a monthly report on the number of "likes" on the advertising post about the photographer's services was obtained. As a result of the studies, it was found that there is a mediate influence of the number of likes on the increase in profit. Data on the sales volume of the photographer's services, quantity likes, expenses, and incomes are presented in table. 1.

It is worth noting, that total costs include both fixed costs (the cost of the camera as depreciation charges distributed per year) and variable costs - the cost of services photo zones, photo salon, photo print for customers. Advertising setup costs, with the help of service Instagram Ad, has been constant for 1 year. 
Table 1 - The economic results of the photographer's activities, (during 2018)

\begin{tabular}{|c|c|c|c|c|c|c|c|c|}
\hline $\begin{array}{r}\text { Month } \\
\text { The }\end{array}$ & $\begin{array}{c}\text { Number } \\
\text { of "likes" } \\
\text { in the ad, } \\
\text { pcs. per } \\
\text { results }\end{array}$ & $\begin{array}{c}\text { Growth } \\
\text { rate (based } \\
\text { on changes } \\
\text { in the } \\
\text { number of } \\
\text { "likes") }\end{array}$ & $\begin{array}{c}\text { Number of } \\
\text { successful orders } \\
\text { (photosessions) }\end{array}$ & $\begin{array}{c}\text { Price for } \\
\text { one order, } \\
\text { UAH }\end{array}$ & $\begin{array}{c}\text { Income, } \\
\text { UAH }\end{array}$ & $\begin{array}{c}\text { Total costs } \\
\text { (Fixed + } \\
\text { Variables), } \\
\text { UAH }\end{array}$ & $\begin{array}{c}\text { Instagram Ad } \\
\text { Costs UAH / } \\
\text { month }\end{array}$ & $\begin{array}{c}\text { Profit, } \\
\text { UAH }\end{array}$ \\
\hline 1 & 100 & - & 0 & 1400 & 0 & 980 & 0 & -980 \\
\hline 2 & 650 & $550 \%$ & 13 & 1400 & 18200 & 12740 & 150 & 5310 \\
\hline 3 & 1675 & $158 \%$ & 18 & 1400 & 25200 & 17640 & 150 & 7410 \\
\hline 4 & 3180 & $90 \%$ & 14 & 1350 & 18900 & 13720 & 150 & 5030 \\
\hline 5 & 3565 & $12 \%$ & 17 & 1400 & 23800 & 16660 & 150 & 6990 \\
\hline 6 & 4120 & $16 \%$ & 23 & 1400 & 32200 & 22540 & 150 & 9510 \\
\hline 7 & 3670 & $-11 \%$ & 21 & 1450 & 30450 & 20580 & 150 & 9720 \\
\hline 8 & 4660 & $27 \%$ & 28 & 1450 & 40600 & 27440 & 150 & 13010 \\
\hline 9 & 4985 & $7 \%$ & 38 & 1450 & 55100 & 37240 & 150 & 17710 \\
\hline 10 & 5370 & $8 \%$ & 40 & 1500 & 60000 & 39200 & 150 & 20650 \\
\hline 11 & 6245 & $16 \%$ & 43 & 1500 & 64500 & 42140 & 150 & 22210 \\
\hline 12 & 7850 & $26 \%$ & 47 & 1500 & 70500 & 46060 & 150 & 24290 \\
\hline
\end{tabular}

The number of "likes" in the advertising post has varied for the study period. The 7th month of 2018 was characterized by a decrease in the number of likes (-11\% growth rate), however, the negative dynamics in this period did not affect the profit, it increased, but not significantly. In this case, the effect of price changes (+50 UAH) on the demand (number of orders) is very clearly traced, and they are reduced but slightly. It should be noted that the advertising post used only one, there were no changes to the description of the photographer's advertising post. During the year, the cost of advertising on Instagram Ad remained unchanged.

The dynamics of growth of the number of "likes" under the advertising post and profit of the photographer's activity are shown in figure 3 .

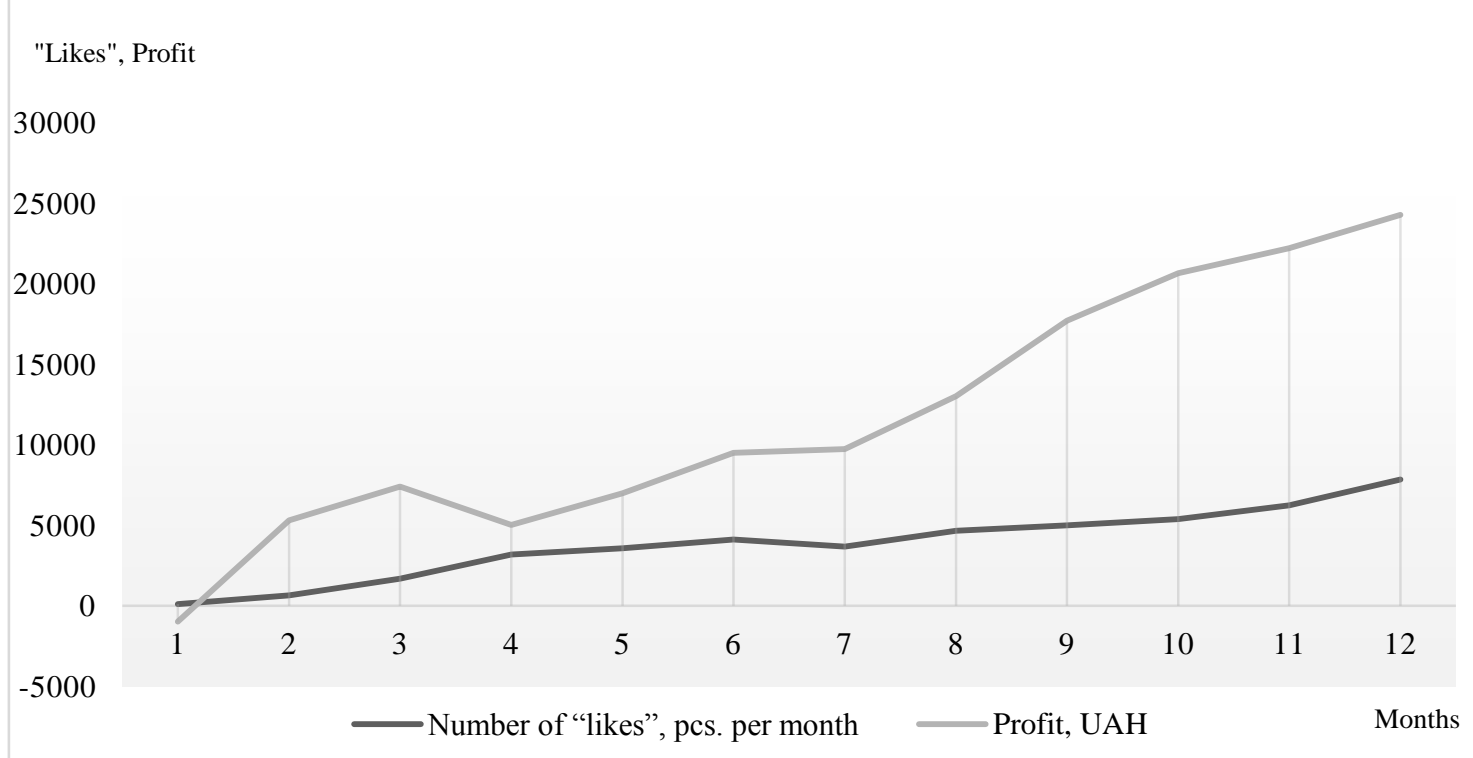

Figure 3. Dynamics of growth in the number of "likes" and profits of the photographer 
The obtained Pearson correlation coefficient in determining the connection between the factor (number of "likes") and the resultant (profit) has proved the hypothesis that there is a direct connection between the number of "likes" under the advertising post and profit. The Pearson correlation coefficient is 0.923 , which proves the total positive linear correlation between the studied factors. And the coefficient of determination, which is 0.85 , confirms the degree of dependence of the variation between the dependent and the independent variables. As the coefficient of determination is close to 1 , this indicates that the obtained observations have confirmed the model.

Figure 4 shows two posts where the naked eye can immediately tell which one is more popular, and the number of likes in each post will help you understand which product is more interesting to the audience.

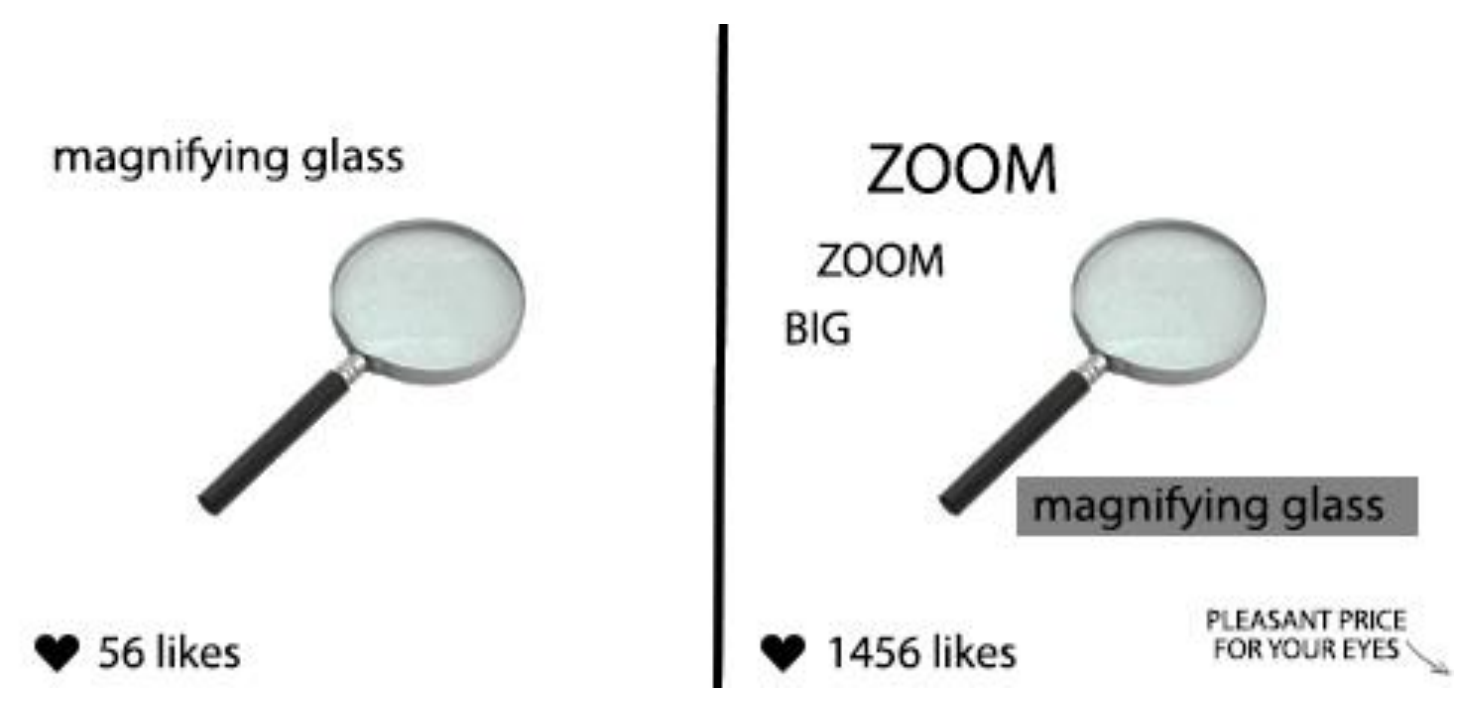

Figure 4. An example of bad quality and quality content on social networks

*Source: Developed by the authors based on their own observations

You can also see the difference between quality content and bad quality content. Placing a photo of the product and its minimal description does not attract customers, but a photo in which a creative description of the properties of the product encourages users to "like" and write a review.

As mentioned above, quality content leads to an increase in likes and reps. But in the course of the company research, it became clear that not all of them "hunt" for many of these components. Some companies do not use social networks as a platform to promote their product at all, but instead see it as more effective in using traditional product promotion tools. In a survey of respondents whose average age is 30 years, it was found that $95 \%$ clearly believe that companies need to use social networks as platforms for promoting and selling goods. It is obvious that the use of social networking companies depends on the product they produce, and yet the effectiveness of Internet marketing is scientifically proven.

An important metric to characterize a company's social media, which testifies to the successful or unsuccessful promotion of a product through posting, is the amount of organic audience reach, that is, how many users have been able to reach after a certain posting time. The tools of this coverage are the like, reposts, and comments. For example, social analytics and monitoring service Socialbakers measured the social impact of a Facebook page (media or brands) receiving the most viral coverage. As Facebook news is traditionally "shared" with 
repost, and brand ratings are only evaluated using "like / dislike," analysts have concluded that a repost is for the media, and for brands, companies, and businesses is "likes" [18].

Recently, more and more companies are using paid social media advertising to reach a larger audience. Most marketers specializing in social networking are seeing a dynamic in likes or reps after the campaign. Paid advertising performance also depends on the content the company wants to promote. According to the same Socialbakers research, brands are increasingly using paid audience reach, and the media is increasingly organic, that is, live audience reach and loyalty. A fidelity is the viciousness of advertising, that is, how quickly a published post is distributed by the social network. The diagrams of distribution of organic reach, paid coverage or faithful reach of the company audience and the media on the example of the social network Facebook are shown in fig. 5 and fig. 6.

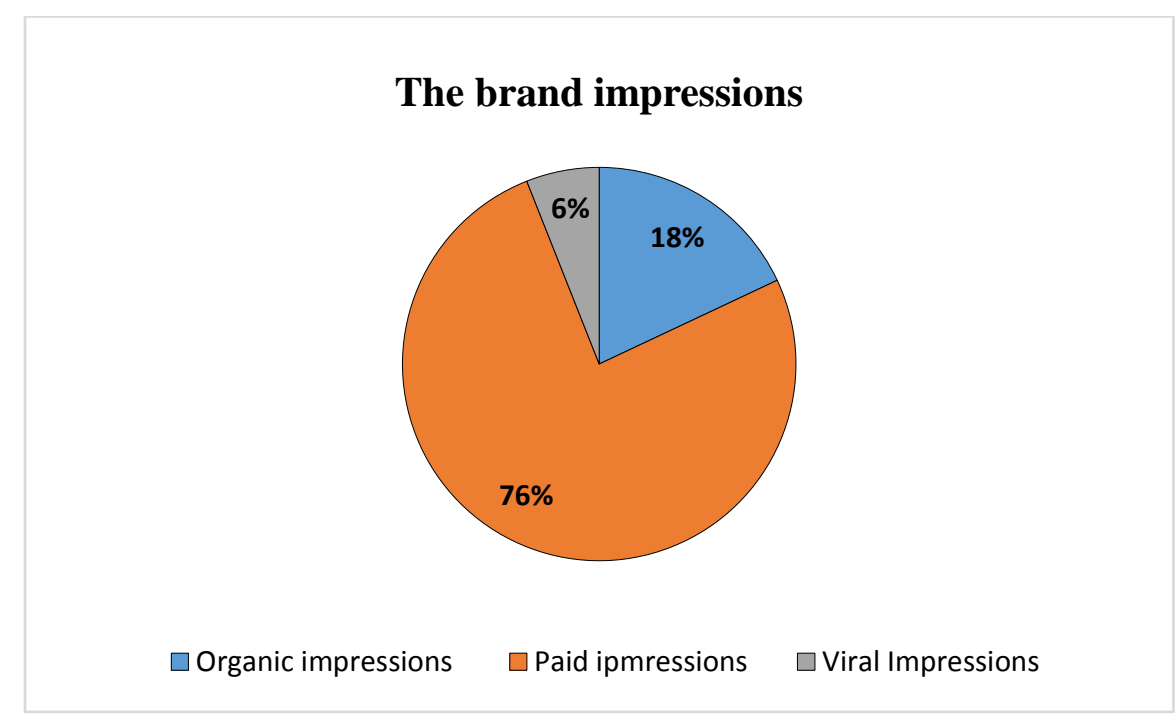

Figure 5. Diagram of the brand impressions *Source: developed by the authors on the basis of [18]

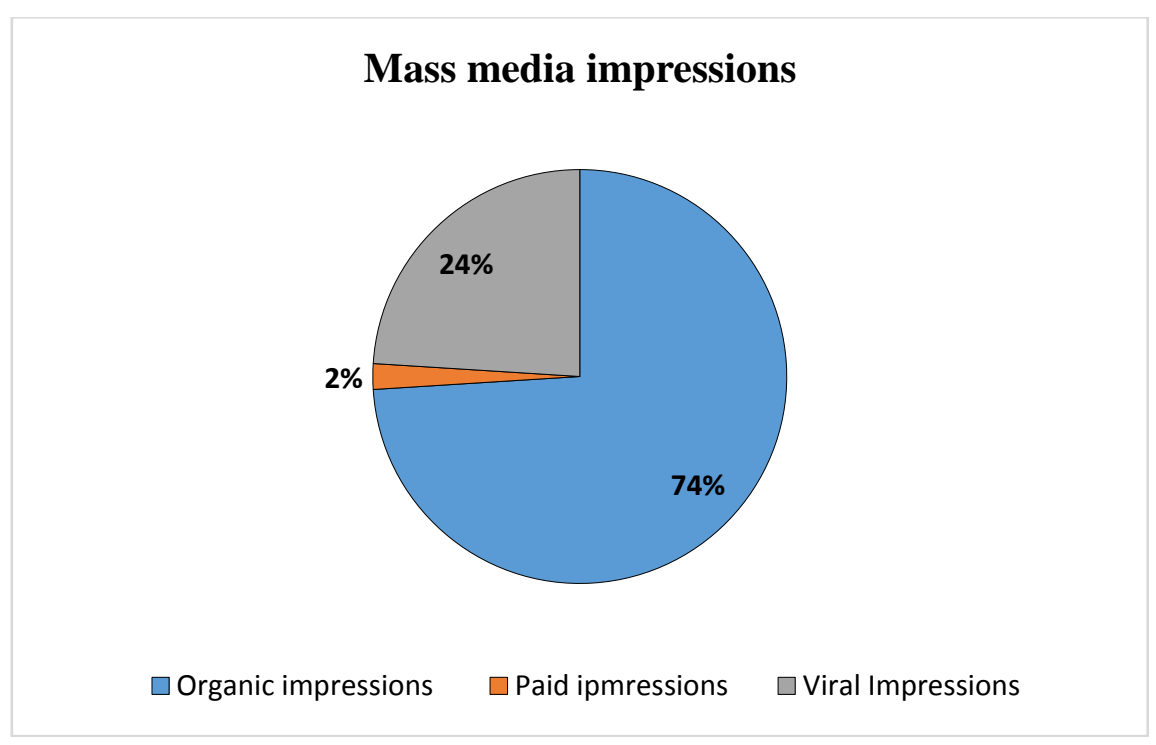

Figure 6. Mass media impressions

*Source: developed by the authors on the basis of [18] 
So, from fig. 5 and fig. 6 clearly shows that companies, in order to increase sales volume, are better to use paid advertising, which will bring significant audience reach and directly lead to an increase in likes. With the media, the situation is dramatically different, where the distributor of information become users directly, the more interesting the news, the greater the more possibly that the user will share it on their own social page.

It should also be noted the detrimental effect of "likes" on users of social networks. The like is a well-known trend that is common among young people (mainly teenagers). Not yet fully understanding the essence of "goodies", active youth hunts for "likes" and gets some (psychological) satisfaction from their number. As an example, the UK government has initiated a bill to improve the safety of children on social networks and called for the removal of the Like button on social platforms. The UK's Office of the Information Commissioner (ICO) has emphasized in the code that this function should be prohibited for children under 18 , explaining it from a psychological point of view as well as from a practical one. A like helps advertisers gather information about users' preferences. Based on this, they set up targeted advertising. The initiator of this project warns that this policy of social networks, including Facebook and Snapchat, may lead to the dissemination of non-child information. Therefore, the Office of the Information Commissioner has included a "age requirement" for "likes" in the recommendations for the use of social networks by children. ISO also suggested disabling automatic location tracking for minors. For companies that do not comply with the rules, ICO proposes to fine up to $\$ 22.6$ million. Such projects have been initiated in Western Europe and North America [19].

A similar project is starting to be introduced by the world-famous social network Instagram, and this has gained even more publicity and panic. What generated this resistance? First of all, this network is characterized by a large number of bloggers, the so-called influencers, who with the help of a large assembled audience promote, advertise companies, brands, and earn on it. The number of likes for influencers is an indicator of their popularity. The higher the number of likes and subscribers, the higher the advertising fee. So, one nutrition and fitness expert from Australia, Jim Wolfie, who has 2.7 million subscribers, complained to national radio that Instagram had removed an important tool for making money. The wave of discontent has increased not only in influencers and bloggers, but also in companies that have worked with these people. For brands, this was one of the most optimal channels of information dissemination, PR. Do not forget about the original mission of Instagram - photo sharing, as well as a network that allows users to take photos, apply filters to them and distribute them through their service and a number of other social networks [13]. Now, this social network has evolved into a "trading platform" where the benefits are gained as unknown companies (those who start a PR campaign) and already popular worldwide brands [20, 21].

Every day, the total number of "likes" seen by all users of the social network. Instagram is about 4.2 billion, of which, more than half, are "likes" put to well-known brands, companies [20]. As already mentioned, such a large number of likes attracts a large number of customers and therefore generates profit for a particular company. In a study conducted by the authors, it was found that only $15 \%$ of respondents are not ready for the changes offered by the social network Instagram - the absence of "likes". 47\% are happy to accept the unrealized innovation, and $35 \%$ believe that the network will lose its essence if it removes the "Like" feature. This initiative was supported by developers of other social networks, such as Facebook, Pinterest. It may be a few years or months later when users will not be able to respond to certain post with like. But there will be other tools that will appeal to users who make money through social platforms and those who spend time online viewing photos or listening to music.

Every year there is a growing trend of changing marketplaces. The main platform for engaging consumers is social networks and websites of business companies. Customers were 
given the opportunity to show their satisfaction with the product by liking or reposting. The number of these labels directly influences consumer behavior. For marketers, keep in mind that 2 of 5 social network users make a purchase by sharing a product note with friends. The Vision Critical studies confirm that social networks affect sales, and "like" and consumer reposts often indicate that the user is ready or willing to buy the products they like [15]. It should be remembered that SMM specialists measure the popularity of a company precisely by the activity of putting "likes", comments and reposts. If a company has received a tip under an advertisement, it means that it has attracted attention to itself and its products. The user took the time to share their impressions on the company's products and therefore became the number one customer who would soon bring in revenue. It's important to keep in mind that most users only need between 100 and 1000 likes in the post to stop flipping a feed and click on the product link.

Conclusions from this research and prospects for further developments in this area. The integration of digital technologies into the marketing field has made adjustments to the promotion, PR campaigns and sales promotion. Increasingly, both well-known companies and only those who are starting out in business are using brand new platforms to find customers, and most importantly, they are finding more powerful tools to influence both potential and regular customers. All the well-known features on social networks have shown such efficiency: likes, reposts, comments. The effect on demand growth by increasing the quantity of one of the above components is scientifically proven. At this stage of the study of the topic it was possible to economically substantiate the essence of this toolkit, to prove its efficiency and to analyze both the positive aspects of using the influence of the number of likes on the users of the social network, as well as the negative aspects.

A promising direction for further research is to establish a quantitative relationship between the increase in likes, reposts and comments and the increase in demand for a product or service.

The positive and negative aspects highlighted in the article should be taken into consideration by any company trying to influence their client by increasing the number of likes (fair or unfair methods). Particular attention is paid to the factors driving the increase in the number of likes, namely the definition of the enterprise's goal of advertising on social networks, target audience selection (targeting) and quality content. The latter plays a major role in increasing the likes, which ultimately leads to increased sales of the product or service

1. Kak otzyivyi i layki menyayut onlayn-torgovlyu [How reviews and likes are changing online commerce]. Cossa Information Portal Website. Available at: https://www.cossa.ru/149/107305/ (accessed: 15/10/2019). (in Russian)

2. Scott W.D. Psychology of Advertising. Internet Archive Website. Available at : https://archive.org/details/psychologyadvert00scotrich/page/2 (accessed 15/10/2019).

3. Myers D. Sotsialnaya psihologiya [Social psychology]. EBook. Humer Library Website. Available at: https://www.gumer.info/bibliotek_Buks/Psihol/mayers/index.php (accessed 19/10/2019). (in Russian)

4. Friedlander K.T. (1926) Put' k pokupatelyu: (Teoriya i praktika reklamnogo dela) [The path to the buyer (theory and practice of advertising)]. Moscow: VSNKh DSP of the USSR. (in Russian)

5. Chaldini R.B. Psihologiya vliyaniya [Psychology of influence]. EBook. Love Read EC Website. Available at: http://loveread.ec/read_book.php?id=51721\&p=1 (accessed 16/10/2019). (in Russian)

6. Holiday R. Marketing of the Future. Growth hacking. Ryan Holiday Website. Available at: https://learn.ryanholiday.net/ (accessed: 15/10/2019).

7. Dopamine, Smartphones and Users: The Battle of Your Own Time. Harvard University Website. Available at : http://sitn.hms.harvard.edu/flash/2018/dopamine-smartphones-battle-time/ (accessed: $15 / 10 / 2019)$. 
8. What is Social Proof and how to leverage it for your success? Devumi Website. Available at: https://devumi.top/social-proof-in-digital-success.html (accessed 16/10/2019).

9. Snezhnyiy kom laykov: kak rabotaet stadnyiy instinkt $v$ internete [The effect of likes: how does herd instinct work on the internet?]. Republic Website. Available at: https://republic.ru/posts/1/1008778 (accessed 15/10/2019). (in Russian)

10. Use of social media in the work of a journalist. Issuu Website. Available at: https://bit.ly/2PwgpfB (accessed 17/10/2019).

11. Chomu foto yaitsia stalo naipopuliarnishym $\mathrm{v}$ istorii Instagram [Why has an egg photo become the most popular in Instagram history?]. BBC News Ukraine Website. Available at: https://www.bbc.com/ukrainian/other-news-46868413 (accessed 02/11/2019). (in Ukrainian)

12. Suprun rozpovila, yak laiky v sotsmerezhakh vplyvaiut na psykhichne zdorovia [United States Department of HHS, Ulyana Suprun described how likes affect mental health on social media]. Glavcom Website. Available at: https://bit.ly/369lv7W (accessed 05/11/2019). (in Ukrainian)

13. Layki i otzyivyi v pomosch onlayn-riteylu [The impact of reviews and likes on online commerce]. SNCE News Website. Available at: https://snce.ru/article/layki-i-otzivi-v-pomoshch-onlayn-riteylu (accessed: 15/10/2019). (in Russian)

14. Kak sotsialnyie seti vliyayut na prodazhi [How do social networks affect sales?]. TextTerra Internet Agency Website. Available at: https://texterra.ru/blog/kak-sotsialnye-seti-vliyayut-na-prodazhi.html (accessed 16/10/2019). (in Russian)

15. Data on how social media promotes purchasing. Vision Critical Website. Available at: https://www.visioncritical.com/blog/new-data-how-social-media-drives-purchasing (accessed: 19/10/2019).

16. Psykholohiia «laikiv» ta «sheiriv» [Psychology of likes and sharings]. Media Sapiens Website. Available at: https://ms.detector.media/mediaprosvita/research/psikhologiya_laykiv_ta_sheyriv/ (accessed: 16/10/2019). (in Ukrainian)

17. Yak sotsialni merezhi vplyvaiut na prodazhi [How do social networks affect sales?]. Slaidik Website. Available at: http://slaidik.com.ua/yak-sotsialni-merezhi-vplivayut-na-prodazhi/ (accessed: 04/11/2019). (in Ukrainian)

18. Socialbakers viral branding survey. Socialbakers Website. Available at: https://www.socialbakers.com/blog/2471-socialbakers-finds-shares-correlate-94-with-brands-viralreach (accessed 18/10/2019).

19. Facebook prosyat ubrat layki [Facebook is asked to remove "likes"]. Lifestyle Today Website. Available at: https://en.segodnya.ua/lifestyle/science/facebook-prosyat-ubrat-layki-1254670.html (accessed: 18/10/2019). (in Russian)

20. Chy vtratyly Instagram-blohery svii biznes pislia zaborony na "laiky" [Have Instagram bloggers lost their business after being banned for likes?]. BBC News Ukraine Website. Available at: https://www.bbc.com/ukrainian/vert-cap-49509435 (accessed 19/10/2019). (in Ukrainian)

21. How to use Instagram social network effectively? Business Insider Website. Available at: https://www.businessinsider.com/instagram-2010-11 (accessed 19/10/2019).

Косар Наталія Степанівна., канд. екон. наук, доцент, дочент кафедри маркетингу $i$ логістики, Національний університет «Львівська політехніка»(Львів, Україна)

Кіндрат Сергій Володимирович., студент кафедри маркетингу $i$ логістики, Національний університет «Львівська політехніка» (Львів, Украӥна).

\section{Економічний феномен «лайків».}

У статті розкрито основні аспекти впливу інструментів соџіальних мереж таких як: «лайки», репости та коментарі на їх користувачів та досліджено зміну попиту на товар чи послугу компанії при використанні підприємствами інструментів Інтернет-маркетингу. Визначено фактори, що впливають на збільшення вподобайок, репостів та зворотнього зв'язку від користувачів сочіальних мереж. Проаналізовано охоплення аудиторії (цільові клієнти) компаній (брендів). Виокремлено основні переваги та недоліки використання «лайків»у соиіальних мережах із наведенням прикладів згубного впливу вподобайок на молоде покоління. 
Подано результати власних досліджень щзодо впливу «лайків», шерингів та відгуків користувачів на збільшення конверсії та безпосередньо попиту на товар чи послугу; розроблено рекомендації щзодо якісного й оптимізованого використання сочіальних мереж та їх інструментарію для просування продукиії підприємств.

Ключові слова: маркетплейс, маркетингові комунікації, інтернет-маркетинг, маркетинг у соціальних мережах, просування брендів.

Received to the editor Decemder, 72019. 